\title{
BALLADS SURVIVING IN THE UNITED STATES
}

\author{
By C. ALPHONSO SMITH
}

$\mathrm{E}$ VERY student of folk-lore has noticed that the last few years have witnessed a remarkable revival of interest in the folk-song. This interest has not been confined to the United States, but it is probably more manifest in the United States because it has here assumed its most definite form. The American people, not having the rich store of antique ballads found, for example, in Germany or Scandinavia or Servia or or Spain, have gone zealously to work to collect the ballads that drifted across with their forebears from England and Scotland and Ireland. The Bureau of Education in Washington issued a bulletin in January, 1914, containing a list of the three hundred and five English and Scottish ballads and urged the teachers of the United States to form ballad societies in each state for the purpose of finding and thus rescuing these valuable folk-songs before it was too late.

That there are three hundred and five English and Scottish ballads, neither more nor less, was first authoritatively established by Professor Francis J. Child, of Harvard, in his monumental work composed in ten books, from 1882 to 1898 , and called The English and Scottish Popular Ballads. Professor Child made no studied attempt to collect the variants of these ballads surviving in the United States but confined his work chiefly to printed or manuscript records of ballads extant or once extant in England and Scotland. What is now needed above all else is that the ballads surviving in the United States through oral tradition be taken down, both words and music, from the lips of those who still sing them. This can best be done by state organizations, each state becoming responsible for the ballads surviving within its borders. As the teachers in the public schools come into closer contact than others with the people who may be thought likely to hand down the ballad tradition, the opportunity for a successful national quest of the ballad lies chiefly with them. The Department of Public Instruction in Virginia, has, for example, recently issued a ballad circular which has not only guided the teachers of the state in 
their search for folk-songs but has already proved of great service to other states.

In this national quest of the ballad the Southern states have been most active and most successful. "Greater progress during 1914," says Professor Reed Smith in the Journal of Amorican Folk-Lore, volume XXVII, April-June, 1915, "was made in the South, particularly in Virginia, than in any other section of the United States. Mr. Phillips Barry of Cambridge reports no additions for New England. Two Southern states, Georgia and Tennessee, make ballad returns for the first time this year. This brings the total of Southern states reporting up to eight." Of the three hundred and five ballads listed by Child, Tennessee reports eight as surviving through oral transmission in her borders, Georgia nine, Texas ten, South Carolina thirteen, North Carolina nineteen, Missouri twenty, Kentucky twenty-four, and Virginis thirty-seven. To this list must now be added West Virginia, which with a folk-lore society founded as late as July, 1915, already reports twelve traditional ballads. With duplicates omitted this makes a total of forty-two traditional ballads in the Southern states out of the seventy-six found in the United States. Nearly half of those reported from the South have been collected in the last two years and seven of them-viz., John of Haselgreon, Robin Hood and Guy of Gisborne, Robin Hood's Death, Robin Hood and Little John, Robin Hood and the Tanner, Robin Hood Rescuing Will Stutley, and Bessy Bell and Mary Gray-have as yet been found nowhere else in the United States. The five ballads most widely distributed in New England are Tho Elfin Knight, Lady Isabel and the Elf-Knight, Lord Randal, Bonny Barbara Allon, and The Gypsie Laddio; the five most widely found in the South are Lady Isabel and the Elf-Knight, Lord Thomas and Fair Annet, Lord Lovel, Bonny Barbara Allen, and The Maid Freed from the Gallows.

Though it is too soon to generalize very confidently about the traditional ballads surviving in the United States, a few conclusions, some of them more in the nature of suggestions, may be at least tentatively hazarded: In 1904 Professor Kittredge, of Harvard, in his valuable Introduction to the one-volume edition of The English and Scottish Popular Ballads, wrote:

Ballad-making, so far as the English-speaking nations are concerned, is a lost art; and the same may be said of ballad-singing. A few of the ballads in Mr. Child's collection are still in oral circulation; but most of them are completely forgotten or are known only in versions derived from print. Among those which survive may be mentioned Lord Randah, The Wifo of Ushor's Well, The Maid Froed from the Gallows, Sir Hugh, and The Twa Sisters. 

1815:

Professor Kittredge now writes, under date of February 20,

When I wrote "The same may be said of ballad-singing" I was of course in error. Ballad-singing is by no means a lost art, either in Great Britain or in the United States. The evidence for its survival has come in since I wrote. If I were now summing up the facts I should modify my statement. As to the rest of the passage, I had no intention of excluding the United States, though I was of course thinking particularly of England and Scotland. Here again I should modify the statement if $I$ were writing at the moment, when more evidence is at hand.

The evidence is that seventy-six of the ballads in Child's collection have been found surviving in the United States and about eighty-five in Great Britain. There is of course a possibility that some of these may owe their survival to print and should not therefore be counted. In my own efforts to collect $\rightarrow$ and I am sure that I speak for all of the ballad collectors whom I know personally -no pains have been spared to eliminate every ballad that can be traced even indirectly to printed sources. Thus a fragmentary version of Chevy Chase was thrown out because it was almost identical as far as it went with Bishop Percy's version, which was never a real ballad. The singer from whose lips the Virginia version came learned it from his mother in whose family "it was traditional"; but, though the singer had seen no printed copy, the ballad was not counted because the printed page had plainly, as it seems to me, been one of the relay-stations in the journey of the ballad from source to singer. When all deductions are made, however, it remains true that ballad-singing is by no means a lost art either in Great Britain or in the United States. Nor is balladmaking a lost art, though that is a different story. Where the old conditions survive, as they do in some parts of the Southern states, the ballad itself survives both as a creative art and as a reproductive art; and one may venture the prophecy that, when the surviving ballads are sifted free of print in both countries, more of the three hundred and five will be found transmitted through unbroken oral tradition in the United States than in England and Scotland.

That ballad-collecting if done at all must be done quickly is shown by the increasing unwillingness of illiterate people to admit a familiarity with these songs. Tact must be exercised, though only in the case of the unlettered, and the unlettered are not, of course, the only depositories of the traditional ballad. One woman, for example, in a neighboring state, when asked about ballads, said: 'Irin't got no time to be studyin' 'bout them old songs, and don't know none of 'em nohow." It is interesting to find that she was 
very proud of her familiarity with many of the Moody and Sankey Sunday-school songs, but looked upon the ballad as allying her with a remote and unspiritual past which she wished to forget. When she had gratified her desire to display her familiarity with Onvard, Christian Soldiers and Hold the Fort, her voice and manner suddenly changed and ten English and Scottish ballads poured forth. A ballad-collector in Virginia writes: "In making inquiries in regard to ballads I have in several cases encountered a strong Puritanical feeling against them. One lady told me she had "prayed to the Lord to take them fool songs out of her mind' and now she never thought of them."

In general it may be said that the American survivals are not as plainspoken as their British prototypes, a change doubtless due to the use of ballads as nursery songs in America. Vulgarity, however, is not a characteristic of the British ballad, though it is almost inseparable from some of the motifs treated. The few ballads that are most off-color in Child's collection either do not survive in the United States or are shorn of their most offending features. Emendations of this sort may be seen in Our Goodman and Little Musgrave and Lady Barnard. In the South Carolina and Virginia versions of The Three Ravens stanza six does not appear. Another characteristic omission is of the supernatural. The Elf-Knight, for example, in the ballad of that name, though not less inhuman in most American variants is not at all superhuman. The same may be said of The Demon Lover, most widely known in America as The House Carpenter.

The change of name in the last-mentioned ballad is a reminder of the frequent and interesting mutilations or substitutions of words and titles found in many American versions. Lord Randal is sung in the mountains of Virginia as Johnnis Randolph, a doubtful compliment to the Virginia statesman. In a veision of Barbara Allen just received, "in the choir" is replaced by "in Ohio." In the Virginia variant of Robin Hood Rescuing Will Stutloy we read that tidings came

That Stutley he surprised was,

In Aiken prison lay;

Three varlets whom the king had hired

Did basely him betray.

In the British version this stanza runs,

That Will Stutley surprised was

And eke in prison lay;

Three varlets that the sheriff had hired

Did likely him betray. 
This mutilation is evidence that the American variant harks back to a period when "eke" still had as in Chaucer's time the sound of modern "ache." It becomes, therefore, a valuable indication of age.

In another ballad the words "sprung a leak" suffer a seachange in the inland American variant to "sprung a leap." The hearer, evidently misunderstanding or mishearing the expression, thought the reference was to the final plunge that the ship made before going down. In Lord Randal the oft-repeated "fain would lie down" becomes in a North Carolina variant "fainting to lie down," showing that "fain" had become meaningless. Even "ivory comb," falling on unfamiliar ears, may become "high-row comb," just as "pen-knife," so dear to ballad heroes and heroines, may be cheapened to "penny-knife." It is rare that the misunderstood term is represented by a meaningless word or phrase, though Miss Mary Johnston, the novelist, writes of hearing a mountain woman sing the first two lines of Lord Lovel as follows:

Lord Lovel stood at his cassy-gate

A-combing his milk-white speed.

It is probable that "steed," meaning nothing to the hearer, found itself easily replaced by the equally meaningless "speed," while "cassy," which often appears as "casten," related itself vaguely in the singer's mind with the "cast" of "cast-iron." Of course such corruptions are not peculiar to America or to the ballad. In Lincolnshire, Sussex, Somerset, and Devon one may still hear "information" for "inflammation," "sentiment" for "sediment," "profligate" for "prolific," "unction" for "auction," "exertion" for "excursion," and numerous congeners. Mrs. Malaprop with her "nice derangement of epitaphs" belongs to the English language rather than to any particular country in which the English language is spoken.

But the most troublesome question raised by the ballad as a distinctive type of literature is that relating to its origin. How were the ballads composed? How did they get themselves launched? The theory that has gained ground most rapidly in recent years is the theory of communal composition. This theory may be summed up in Grimm's words, "Das Volk dichtet," though it should be said that this exact quotation has not yet been found in Grimm's works. Communal composition means composition not by an individual, as all poetry except the ballad is composed, but by a group. A leader starts off and the others "chip in," the result being a song composed not by one but by all. 
Such a song is sure to be characterized by repetition and parallelism, repetition of words, phrases, and lines, and parallelism in the structure of sentences and stanzas. Professor Kittredge cites as an illustration The Hangman's Troe, a North Caroline variant of The Maid Freed from the Gallowos:

\section{1}

Hangman, hangman, howd [hold] yo hand, $O$ howd it wide and farl

For theer I my father cooming Riding through the air.

\section{$\&$}

Father, father, ha yo brought me goold?

Ha yo paid my fee?

Or ha yo coom to see me hung

Beneath the hangman's tree?'

\section{8}

I ha naw brought yo goold, I ha naw paid yo fee,

But I he coom to see yo hung

Beneath the hangman's tree.

\section{4}

Hangman, hangman, howd yo hand, 0 howd it wide and farl

For theer I see my mother cooming Riding through the air.

\section{$\delta$}

Mother, mother, ha yo brought me goold? Ha yo paid my fee?

Or ha yo coom to see me hung

Beneath the hangman's tree?

\section{6}

I ha naw brought yo goold,

I ha naw paid yo fee,

But I ha coom to see yo hung

Beneath the hangman's tree.

\section{7}

Hangman, hangman, howd yo hand, 0 howd it wide and far!

For theer I see my sister cooming Riding through the air. 
Ballads Surviving in the United States

8

Sister, sister, ha yo brought me goold?

Ha yo paid my fee?

Or ha yo coom to see me hung

Beneath the hangman's tree?

9

I ha naw brought yo goold,

I ha naw paid yo fee,

But I ha coom to see yo hung

Beneath the hangman's tree.

10

Hangman, hangman, howd yo hand, $O$ howd it wide and far!

For theer I see my sweetheart cooming Riding through the air.

11

Sweetheart, sweetheart, ha yo brought me goold?

Ha yo paid my fee?

Or ha yo coom to see me hung

Beneath the hangman's tree?

12

$O$ I ha brought yo goold,

And I ha paid yo fee,

And I ha coom to take yo froom

Beneath the hangman's tree.

Suppose now, says Professor Kittredge, that The Bangman's Troo is a new ballad, sung for the first time by the improvising author. The audience are silent for the first two stansas and until the first line of the third has been finished. After that, they join in the song. So inevitable is the course of the narrative, so conventionally fired the turn of the phraseology, that they could almost finish the piece by themselves if the author remained silent. At most they would need his prompting for "mother," "sister," and "sweetherrt" in stanzss 4, 7, and 10, and for a few words in stanes 12. If, in accordance with an hypothesis which is justifiable in many cases, they were familiar with the outline of the plot, though they had never heard a ballad on the subject, they would not require even so much assistance as this. The song is ended, the crestive act of composition is finished-and what has become of the author? He is lost in the throng.

That is what might have taken place and perhaps did. But cannot an actual as well as a theoretical illustration of communal composition be given? Professor Gummere, to whom also all students of the ballad are deeply indebted, in defending himself 
against the charge of vagueness, says, in The Nation of August 29, 1807: "Professor Kittredge has shown how a ballad like The Hangman's Tree could be improvised in a crowd, and by a crowd; and my object was to prove that the ballad structure itself is derived from choral repetition." In The Popular Ballad (1907), page 101, Professor Gummere refers again to the same illustration, The Hangman's Tree, adding that Professor Kittredge has shown by this ballad "how easily mere choral singing of a crowd, with slightest touch of invention, could improvise a ballad." In his Domocracy and Poetry (1911), page 193, Professor Gummere cites the same ballad once more, saying: "Indeed, the making of a whole poem by choral improvisation out of this communal material has been proved by Professor Kittredge in. the case of a traditional English ballad called The Hangman's Tree."

The word "proved" seems to me to claim far more than Professor Kittredge implies in his illustration. Professor Kittredge has made clear what might have been, but he has "proved" nothing more than that the phrase "communal composition" had in his own mind a perfectly definite connotation. To "prove" communal composition one must draw his illustrations from processes going on around him and actually seen or from processes accurately reported.

I am more and more convinced that a thorough study of the camp-meeting songs of the American negro is destined to throw new light on this vexed question of communal composition; and the renewed investigations of ballad origin and ballad structure, with which American scholarship is beginning to busy itself, will tend more and more to hasten this consummation. If one will attend a negro revival in the country or in the suburban districts of the Southern states he can see and hear this process of communal composition, about which so much has been written and surmised, carried on into the wee hours of the morning. Here are a few illustrations taken from $A$ Collection of Rovioal Hymns and Plantation Melodies by Marshall W. Taylor, D. D. (Cincinnati, 1883), and from the standard Religious Folk-Songs of the Negro as Sung on the Plantation, fourth edition, by Robert R. Moton (Hampton, Va., 1909). They are simpler than The Hangman's Tree, the unit of repetition being one stanza instead of three. After the song is started, each first line is as a general thing the contribution of a different improviser. These songs are, of course, too subjective to be called ballads in the restricted sense. They lack the note of impersonality. But they seem to me the best illustration of communal authorship as actually practised today: 
From Taylor's collection:

SAvm Me, Lord, SAfe ME.

1. I called to my father;

My father hearkened to me,

And the last word I heard him say

Was, Save me, Lord, save me.

2. I called to my mother, etc.

3. I called to my sister, etc.

4. I called to my brother, etc.

5. I called to my preacher, etc.

6. I called to my leader, etc.

7. I called to my children, etc.

He Sex Mr Soul Frow.

1. Go and call the bishops in,

Go and call the bishops in,

Go and call the bishops in,

And ask them what the Lord has done.

\&. Go and call the elders in, etc.

8. Go and call the deacons in, etc.

4. Go and call the leaders in, etc.

5. Go and call the Christians in, etc.

\section{Rhguarection or Cerrigt.}

1. Go and tell my disciples,

Go and tell my disciples,

Go and tell my disciples,

Jesus is risen from the dead.

2. Go and tell sister Mary and Marthe, etc.

8. Go and tell poor sinking Peter, etc.

4. Go and tell the Roman Pilate, etc.

5. Go and tell the weeping mourners, etc.

From Moton's collection:

\section{ROLL, JORDAN, ROLL.}

1. O brother, you ought $t$ 'have been there, Yes, my LordI

A-sitting in the kingdom

To hear Jordan roll.

2. O sister, you ought t'have been there, etc.

3. O preacher, you ought t'have been there, etc.

4. O sinners, you ought t'have been there, etc. 


\section{Gonvo to Shout Arc Over God's Henv's}

1. I've got a robe, you've got a robe, All of God's children got a robe; When I get to Heaven, goin' to put on my robe, Goin' to shout all over God's Heav'n.

\&. I've got a crown, etc.

3. I've got a shoes, etc.

4. I've got a harp, etc.

5. I've got a song, etc.

\section{Rmiaton Is a Fortuns.}

1. Oh, religion is a fortune, $I$ raly do believe, $\mathrm{Oh}$, religion is a fortune, I raly do believe, $\mathrm{Oh}$, religion is a fortune, I raly do believe, Whar sabbaths have no end.

2. Gwine to sit down in de kingdom, I raly do believe, etc.

8. Gwine to see my sister Mary, I raly do believe, etc.

4. Gwine to talk-a wid de angels, I raly do believe, etc.

It should be needless to say that these typical "spirituals" are contracted or expanded as occasion demands or time permits, the number of stanzas here given being by no means final. These stanzas, however, contain the start and enough of the continuation to show what the unit of repetition is and how the song is built up by swinging the stanza around the successive pivotal words contributed by the different singers. Neither is the version here given of The Hangman's Tree a final version, though in all versions "sweetheart" or "true love" must come last, just as "Jesus" or "my Jesus" comes last in many of the similarly built negro songs.

The Hangman's Tree, by the way, which survives in England as The Prickly Bush, seems to have become peculiarly the property of negroes, at least in Virginia. This is due, I think, to the adaptability of the theme and the easily remembered framework of the stanzas, qualities that mark the intersection of the ballad proper and the negro camp-meeting song as types. In a variant received from a negro girl in Gloucester County, who "learned it from her grandmother," it is a golden comb that has been lost and it is the true love that finds it. The first triad runs:

O hangman, hold your holts, I pray, 0 hold your holts awhile,

I think I see mylgrandmother A-coming down the road. 


\section{Ballads Surviving in the United States}

$O$ have you found $m y$ golden comb? And have you come to set me free?

Or have you come to see me hanged On the cruel hangman tree?

I have not found your golden comb, Nor have I come to set you free.

But I have come to see you hanged On the cruel hangman tree.

In another variant from Franklin County it is not a maid who is freed but a man, the terminal true love being the maid. The first line is inimitable:

$O$ hangerman, hangerman, slack on your rope, And wait a little while;

I think I see my father a-coming, And he's traveled for many a long mile.

0 father, 0 father, have you brought me money, And money to pay my fee?

Or have you come to see me hanged Upon this hangerman's tree?

$O$ no, my son, I've brought no money, No money to pay your fee;

Yes, I have come to see you hanged Upon this hangerman's tree.

But the most remarkable discovery in connection with this ballad, which is Finnish, Esthonian, Russian, and Sicilian as well as British, is that it is popular among the negroes of Virginia, and among them alone so far as reported, not only as a ballad but as an out-of-doors drama. Of three letters received, the following from a teacher in the State Normal School of Harrisonburg, Virginia, is the most detailed. It is dated May 27, 1913. The place where the ballad was enacted was Scottsville, on the southeastern edge of Albemarle County:

It was a long time ago-probably twenty-five years-at the colored school-house, as a part of the closing exercises of the school. We young people always attended these exercises if possible, because we were sure of being highly entertained. This particular play I remember better than any other I ever gaw there because we thought it so very funny, though plainly intended to be 80 very sad. They had on the stage a rather rude representation of the upper part of a scaffold. A rope the size of a man's wrist was thrown over the cross-beam, one end being tied around the neck of a most dejected-looking girl and the other end held in the hand of a middle-aged man of sternest aspect. She alone did any singing. The apparently endless procession of relatives 
recited their parts very glibly until at last when her "true love" arrived he sang his part, and then the lovers ended the play with a joyous duet. I did not know then that it was a ballad.

But there will never be a real renaissance of ballad interest in the United States until we realize that the ballad is unique not only in its origin but in its perpetuation. In other words these ballads that survive are not already made but are still in the making. There is no standard version of any living ballad in the sense in which we speak of the standard version of Gray's Elogy or Poe's Ravon. When Gray and Poe died their poems ceased to be malleable material. But as long as a ballad circulates by oral transmission it is always in process of making or re-making. The first version, if we could catch it hot from the lips of the composing throng, would not, through mere priority, be one whit more authentic or authoritative than the latest version, provided the latest version was also the product of the people. Let us think of a ballad as a thought or deed or situation or incident or motif adventuring forth to get itself artistically expressed. The standard version, if one insists on the word, is merely the most adequate incarnation that the wandering concept is fortunate enough to assume: it is the best version, whether made in Great Britain or America, whether the child of the fifteenth or the twentieth century.

Barbara Allon furnishes a good example. Here is the usual British version:

$$
1
$$

It was in and about the Martinmas time, When the green leaves were a-falling,

That Sir John Graeme in the West Country, Fell in love wth Barbara Allen.

\section{2}

He sent his man down through the town, To the place where she was dwelling:

"O haste and come to my master dear, Gin ye be Barbara Allen."

\section{9}

O hooly, hooly rose she up,

To the place where he was lying,

And when she drew the curtain by,

"Young man, I think you're dying."

\section{4}

"O it's I'm sick, and very, very sick, And ' $t$ is a' for Barbara Allen":

" $O$ the better for me ye's never be, Tho your heart's blood were a-spilling. 


\section{6}

"O dinna ye mind, young man," said she,

"When ye was in the tavern a-drinking,

That ye made the healths gae round and round, And slighted Barbara Allen?"

6

He turned his face unto the wall, And death was with him dealing:

"Adieu, adieu, my dear friends all, And be kind to Barbara Allen."

\section{7}

And slowly, slowly raise she up, And slowly, slowly left him,

And sighing said, she coud not stay, Since death of life had reft him.

8

She had not gane a mile but twa,

When she heard the dead-bell ringing,

And every jow that the dead-bell geid.

It cry'd, Woe to Barbara Allen!

\section{$\boldsymbol{\theta}$}

"O mother, mother, make my bedl

$O$ make it saft and narrow!

Since my love died for me to-day,

I'll die for him to-morrow."

The printed versions vary but little from the incidents as here narrated. But the story as a story has always seemed to me to be flawed by the silence of Sir John under the accusation brought against him. The reader infers, of course, that Barbara's charge in stanza five is unjust but, in view of the tragic dénouement, artistic balance demands some sort of exculpatory answer from Sir John. At any rate, I felt a sense of profound relief when a version came in from Buchanan County, Virginia, with four additional stanzas. The singer had never seen a printed copy of the song but had always heard it and sung it with these stanzas in place of stanza five:

"Do you remember the other day When we were at the tavern drinking,

You drank a health to the ladies all

And you slighted Barbara Ellen?"

"Yes, I remember the other day When we were at the tavern drinking; I drank a health to the ladies all And three to Barbara Ellen." 


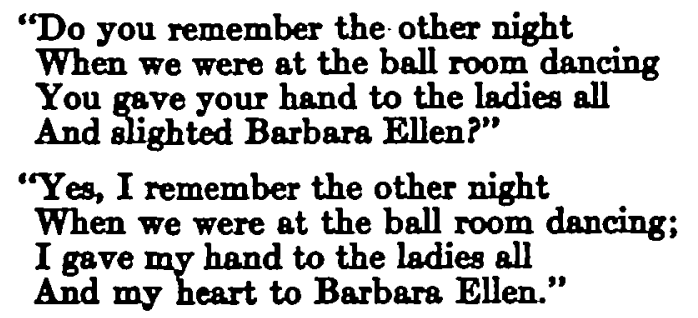

It is possible of course that this better constructed version may be as old as any version known to us. All that weknow of any printed and dated British version is that at that particular time the ballad was intercepted by an interested collector. It may have been a hundred or two hundred years old before it got itself printed, it may have already crossed over to America, and it may have existed all this time in a score of variants or versions. The collector halts only one of them and that only long enough to get a copy. The other versions and the version from which the copy has been made pursue their way from lip to lip and from century to century, though the printed version has now an advantage. When it comes into contact with what may really be an older oral version or with a later oral version or with the now changed oral version that was once its own unembodied self, it is apt to put on airs, merely because, having ink in its veins, it has been associating with books and bookish folk. But the chances are that it is merely a case of arrested development. It is only a painful of stagnant water once dipped from a running stream.

Of course there are cases, like "Aiken" for "eke in" or "sprung a leap" for "sprung a leak," where there is no question of origin or superior merit. But when variants of the same ballad differ in the incidents narrated, in the motifs developed, in the characters introduced, in the epic fitness of detail to dénouement, we have no right to turn to a version printed at a particular time and give it the honors of priority or primacy. This, however, is the popular tendency today. Till it is checked, ballad-hunting in America will be neither as intelligent nor as exhilarating as it ought to be.

The same may be said of ballad melodies. There is a widespread feeling in America not only that the ballad tunes found in British books are older than the tunes sung to the same ballads in America but that the British tunes are the "parents and original" of the American tunes. Like the question of ballad texts the question of ballad music can be settled only by an appeal to facts, but the appeal to facts is here more difficult. Professor Child's industry has provided us with at least a specimen text for each of the three hundred and five British ballads. These texts are usually 
dated and, though the dates signify little that is ultimate, they at least assure us that these were the words and these were the stanzas of a particular version of a particular ballad at a particular time. There is, therefore, a certain basis for the comparison of American texts with British texts. But ballad music has been neglected. Of the three hundred and five British ballads to which we have words, my own search through British song books has revealed only about twenty with music. There are doubtless many more but, until they are made generally accessible, comparison will have to be tentative and provisional.

The nature and history of the ballad, however, should guard us against pre-supposing that our American ballad melodies are lineal descendants of, or even more youthful than, the melodies found here and there in British song books. America, it must be remembered, was settled at a time when ballads were sung more widely in Great Britain than now but before the words or the music of a majority of the three hundred and five had been transcribed. The versions brought over, therefore, may be in some cases lineal descendants but they may also be older. They may go back to textual and melodic variants which not only antedate the surviving British variants but which in some cases left no lineal British issue.

In the case of the following ballad, for example, which goes under the names of Sir Hugh, The Jow's Daughtor, The Duke's Daughter, Little Barry Hughes, The Little School Boy, and Bugh of Lincoln, the Irish melody bears apparently no relation, direct or indirect, to either of the other two, and $B$ and $C$ also seem unrelated to each other:
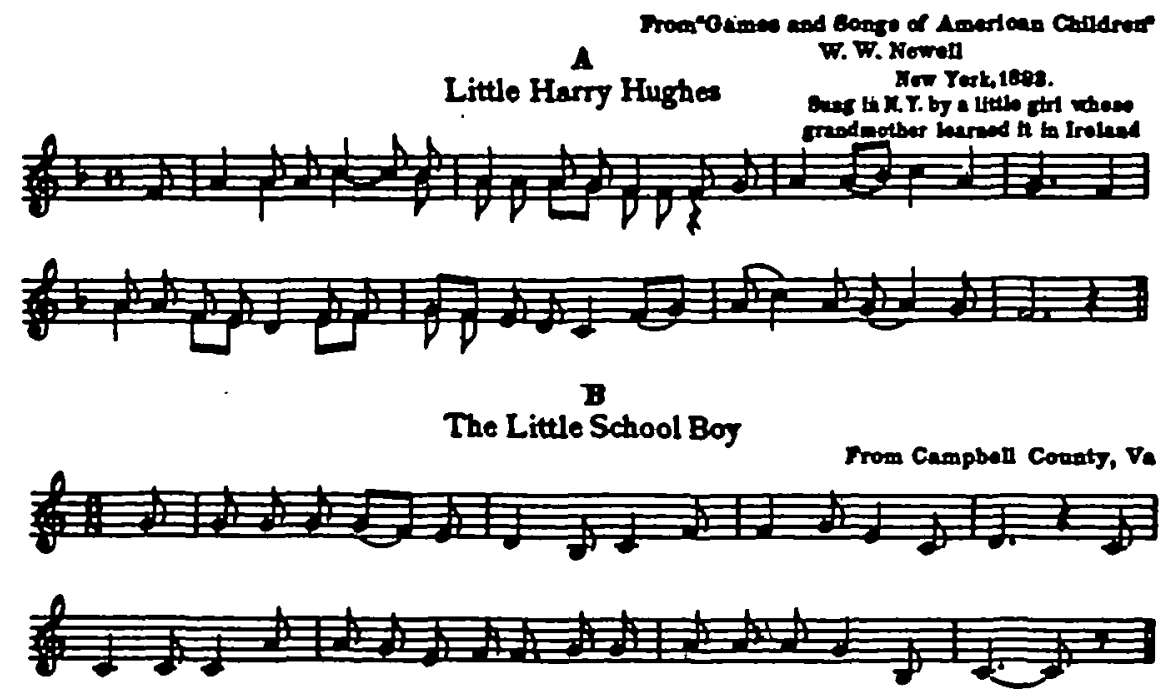
0

Sir Hurot

Trom Rooktoman Corints, 5
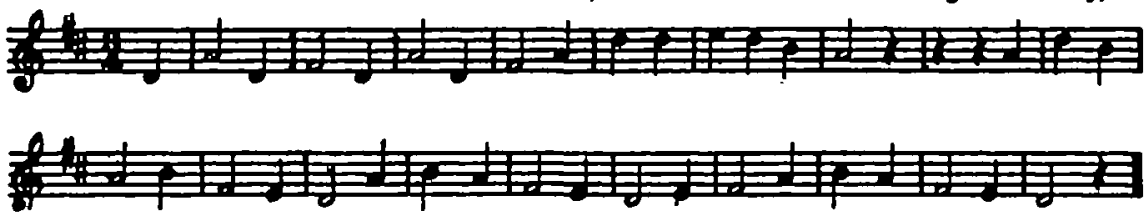

The event narrated in Sir Bugh took place in the year 1255 but the melody heard by Mr. Newell seems to have been influenced by the rag-time syncopation characteristic of negro music. In fact Mr. Newell first heard the song "from a group of colored children in the streets of New York" and then succeeded in tracing it to an Irish source. The following interesting version without the music was handed me by a student at the University of Virginia who learned it in childhood from his negro mammy on a plantation a few miles from Montgomery, Alabama:

1. My ball flew over in a Jew's garden, Where no one dared to go,

I saw a Jew lady in a green silk dress A-standing by the do'.

2. "Come in, come in, my pretty little boy, You may have your ball again."

'I won't, I won't, I won't come in, Because my heart is blood."

8. She took me then by her lily-white hand, And led me in the kitchen, She sot me down on a golden chair, And fed me on sugar and rice.

4. She took me then by her lily-white hand,

And led me in the kitchen,

She laid me down on a golden plank, And stobbed me like a sheep.

6. You lay my Bible at my head, And my prayer book at my feet, And if any of my playmates they ask for me, Just tell them I've gone to sleep.

The ballad known as Our Goodman or Hame Cam' Our Gudoman, which has spread from Great Britain into Scandinavia and Hungary via Germany, is sung among certain of the negroes of 
Campbell County, Virginia, as Hobble and Bobble. The melodies here given are plainly if not closely related:

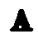

Hame Cami Our Gudomen at E'en

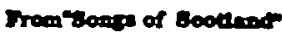
Miles B. Fontor, Vol I Lendoe end Itertert (at dated)

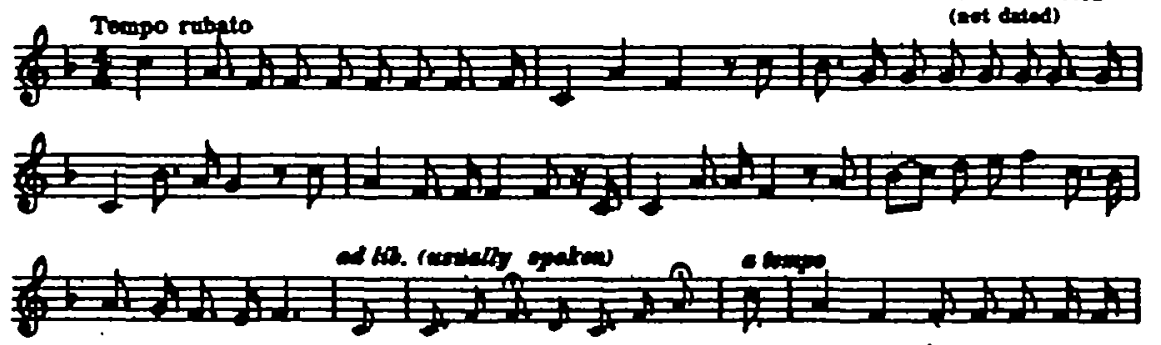

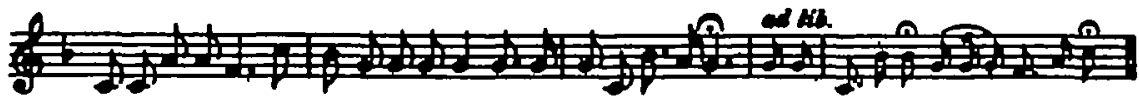
:20 B

Hobble and Bobble From the dengtas af a colored men to Cenpben Conntr, Va.
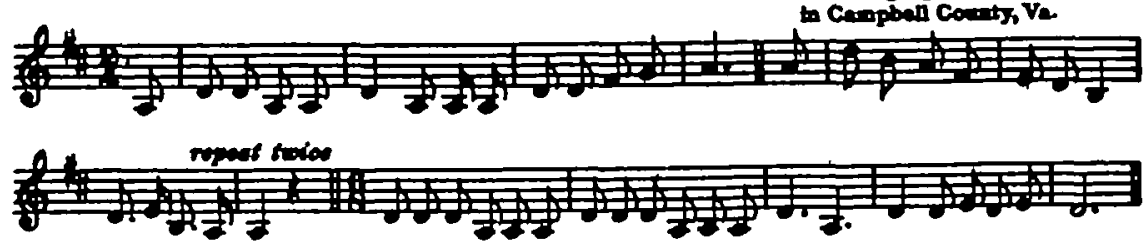

o

Home Comes the Good Old Man Prom Oampin County, va

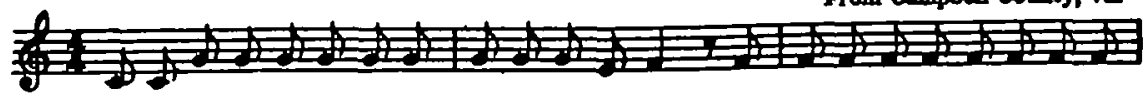

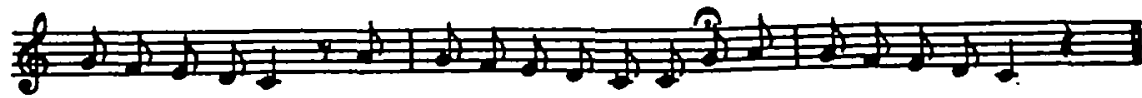

Variants of Our Goodman without music have also come from the mountains of North Carolins. One of the best is from Rockingham County, Virginia. The first four stanzas, which may be counted as two, are:

Down came the old man

Hummin' like a bee,

Found a horse a-standin'

Where his own ought to be. 
He turned to his wife And he said unto she, 'What's this horse a-doin' here Without the leave o' me?"

\section{8}

"You old fool, you blind fool, You fool, you cannot see; It's nothing but a milk cow My mother sent to me."

"T've traveled many miles, And many miles before, A saddle on a milk cow I never saw before."

I have been unable to find in English or Scottish collections the music either to Lady Margaret, better known in Great Britain as Fair Margaret and Swoet William, or to The Demon Lover, better known in America as The House Carpenter; but A and B seem akin in both of these renderings:

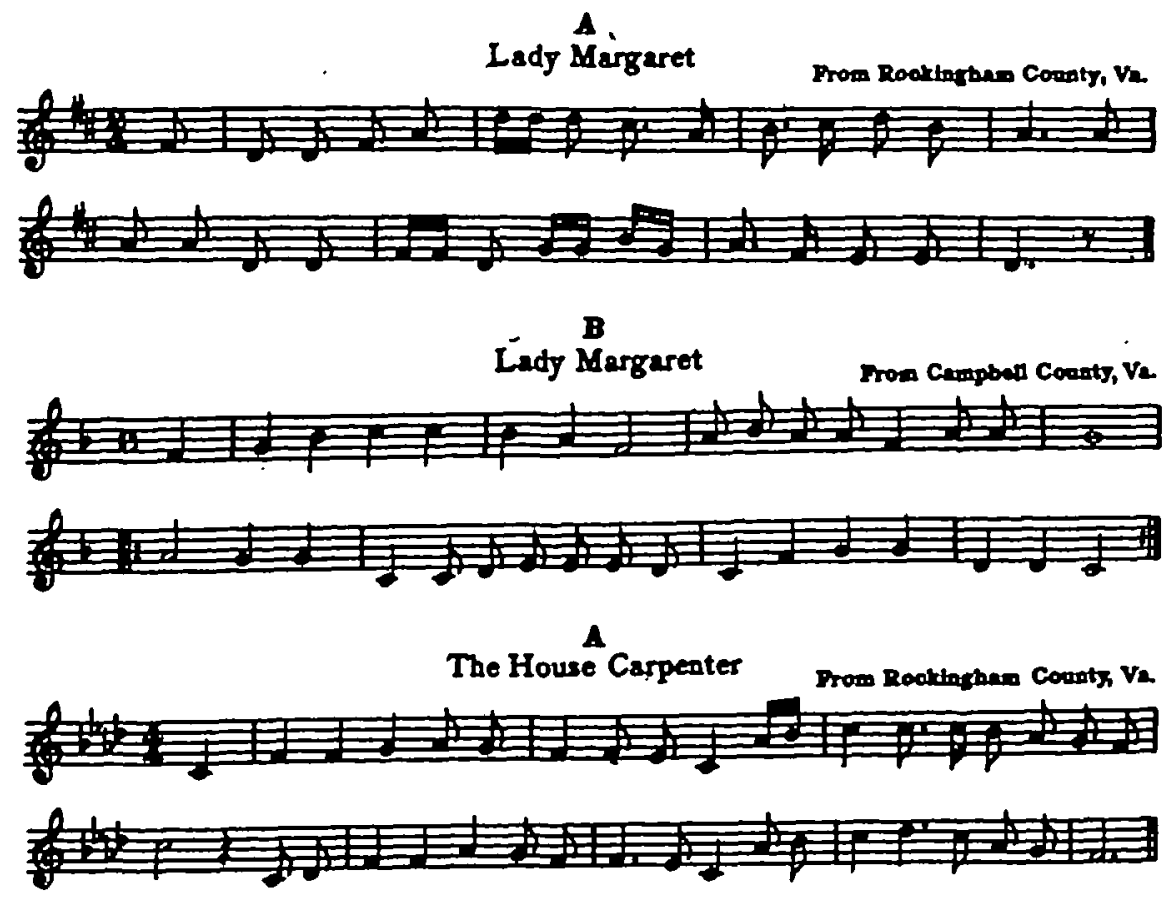


B

The House Carpenter

Trom Campoull Coonts Va.
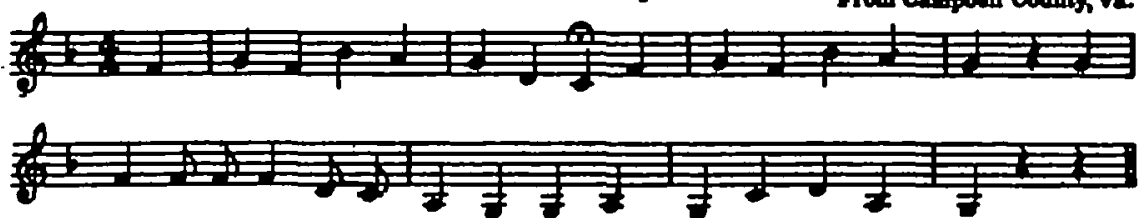

The ballad of Lord Randal or Lord Ronald, though more than two hundred and fifty years old in Italy, has not been found in written form earlier than 1808 in Great Britain. Its lack of years, however, is more than atoned for by its multiplicity of names. Lord Lantoun, Swoot William, Fair Elson, Swoet Nelson, Johnnic Randolph, Johnnic Rillor, John Willow, Toronto, Tyrante, Tyranting, Terence, Orlando, Fileander, Dandoo, and Durango are some of the titles under which it circulates, though a few versions show a tendency to abolish proper names and to take as label the more non-committal first line, Where have you been to, my dear son?
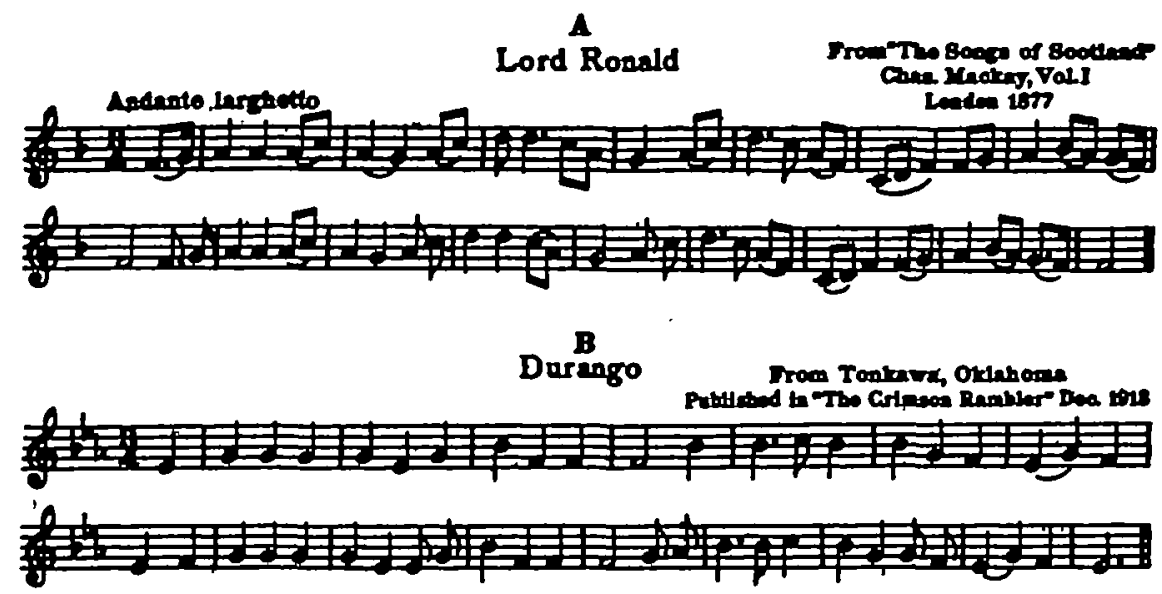

The differences between these melodies, especially when we take into consideration the comparatively short time left for divergence, point to a remote original rather than to the lineal descent of one from the other. Variants without music have come from many counties in Virginia, and a rather domesticated version from the East Side, New York. It begins:

"Where have you been all day, Henry, my son?

Where have you been all day, my loving one?"

'Down at grandma's, down at grandma's!

Make my bed, I've a pain in my head,

And I want to lie down and die." 
This is the only version received that makes the brother the villain. It ends:

"What did you leave to your brother, Henry, my son?

What did you leave to your brother, my loving one?"

"A rope to hang him, a rope to hang himl

Make my bed, I've a pain in my head.

And I want to lie down and die."

Among the following musical arrangements of Barbara Allen, one from Scotland, one from England, and five recently transcribed from the lips of the singers in Virginia, no one of whom understood music, the differences are so great that it would hardly be safe to select any two and say that they are related by direct derivation, though four are current in the same county:
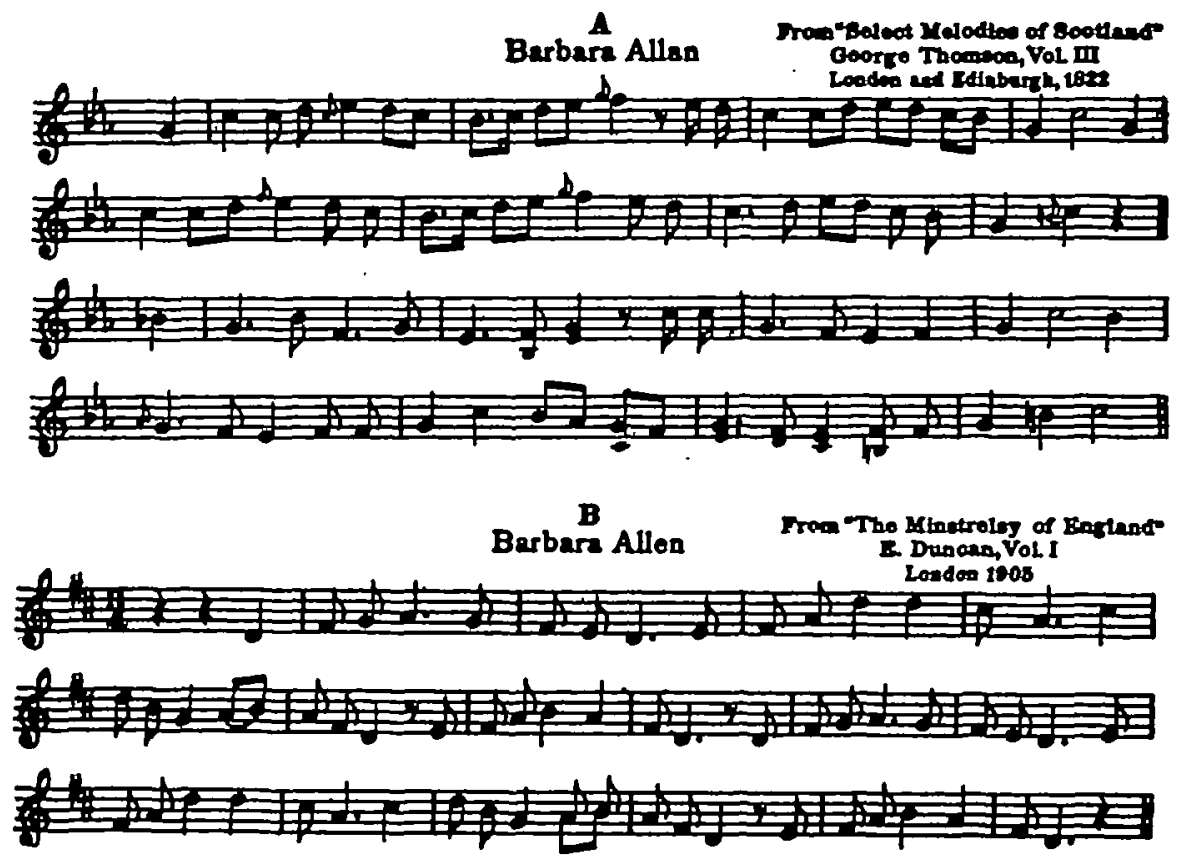

o

Barbare Allen

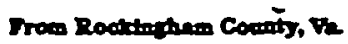
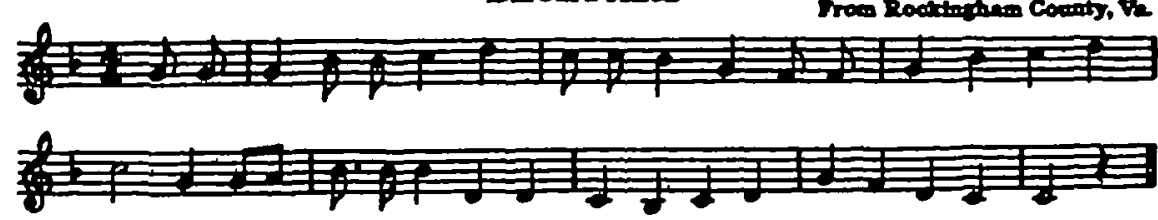


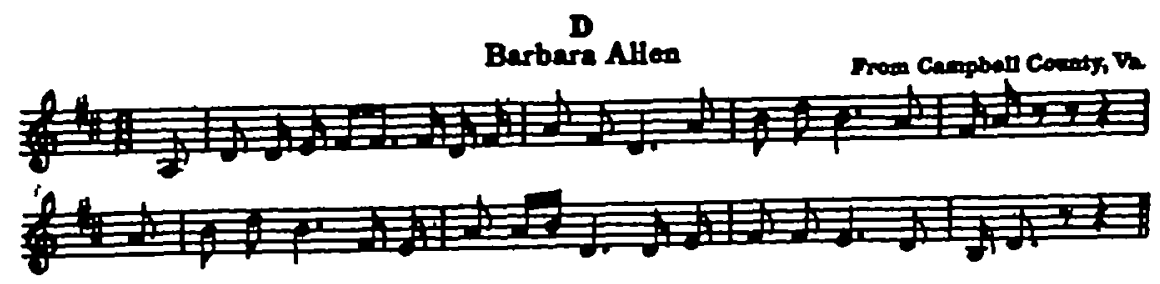

B
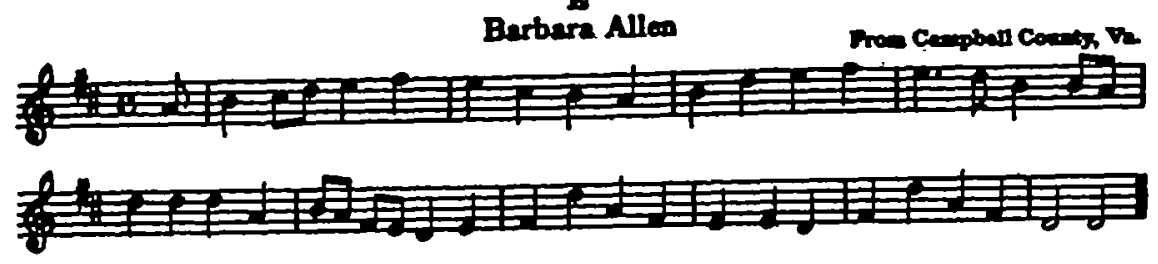

$\mathbf{P}$

Barbara Allen

Tras Cumpoll County, Ve.
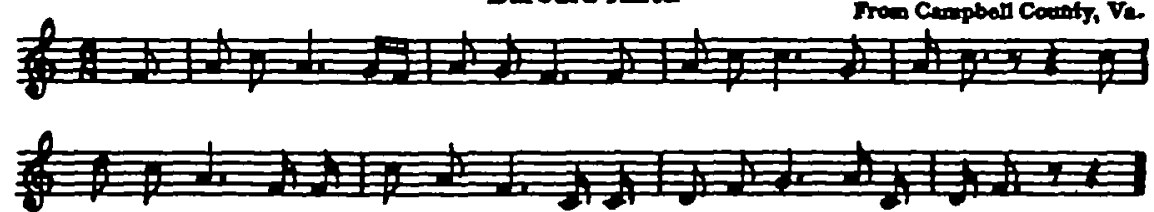

$\theta$

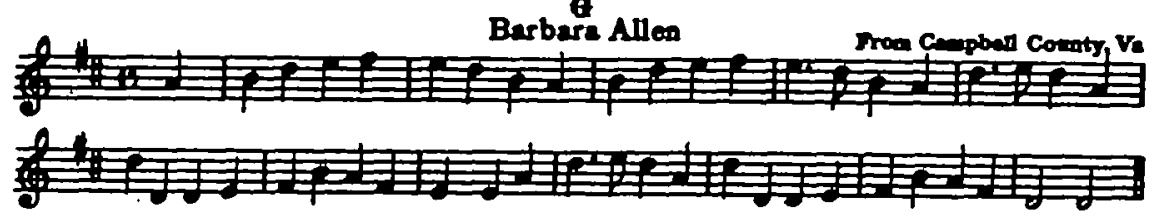

Even if a similar strain be heard in A, C, and F, and if $E_{\text {l be }}$ found to suggest $G$, the relationship would seem to be collateral rather than lineal. Priority, in other words, can hardly be affirmed of any of these melodies until more data be thrown upon the scales. When Pepys in 1666 lauded the "little Scotch song of Barbary Allen" and when Goldsmith a century later declared that "the music of the finest singer is dissonance to what I felt when our old dairy-maid sung me into tears with Johnny Armstrong's Last Goodnight or The Cruelty of Barbara Allon," both may have been praising, so far as we know, a melody unrecorded in books and heard today, if heard at all, only in some shadowed lane or mountain cove or lonely farm-house of the United States. Who can say? The truth is that the ballad heritage of the English-speaking race has been studied as poetry but not as song. Yet it was as song that the balled was born and it is as song that it survives. 